\title{
Front Matter: Volume 6671
}

, "Front Matter: Volume 6671," Proc. SPIE 6671, Optical Manufacturing and Testing VII, 667101 (21 September 2007); doi: 10.1117/12.773469

SPIE Event: Optical Engineering + Applications, 2007, San Diego, California, United SPIE. States 


\section{PROCEEDINGS OF SPIE}

\section{Optical Manufacturing and Testing VII}

James H. Burge

Oliver W. Faehnle

Ray Williamson

Editors

28-29 August 2007

San Diego, California, USA

Sponsored and Published by

SPIE

Volume 6671 
The papers included in this volume were part of the technical conference cited on the cover and title page. Papers were selected and subject to review by the editors and conference program committee. Some conference presentations may not be available for publication. The papers published in these proceedings reflect the work and thoughts of the authors and are published herein as submitted. The publisher is not responsible for the validity of the information or for any outcomes resulting from reliance thereon.

Please use the following format to cite material from this book:

Author(s), "Title of Paper," in Optical Manufacturing and Testing VII, edited by James H. Burge, Oliver W. Faehnle, Ray Williamson, Proceedings of SPIE Vol. 6671 (SPIE, Bellingham, WA, 2007) Article CID Number.

ISSN 0277-786X

ISBN 9780819468192

Published by

SPIE

P.O. Box 10, Bellingham, Washington $98227-0010$ USA

Telephone +1 3606763290 (Pacific Time) · Fax +1 3606471445

SPIE.org

Copyright (c) 2007, Society of Photo-Optical Instrumentation Engineers

Copying of material in this book for internal or personal use, or for the internal or personal use of specific clients, beyond the fair use provisions granted by the U.S. Copyright Law is authorized by SPIE subject to payment of copying fees. The Transactional Reporting Service base fee for this volume is $\$ 18.00$ per article (or portion thereof), which should be paid directly to the Copyright Clearance Center (CCC), 222 Rosewood Drive, Danvers, MA 01923. Payment may also be made electronically through CCC Online at copyright.com. Other copying for republication, resale, advertising or promotion, or any form of systematic or multiple reproduction of any material in this book is prohibited except with permission in writing from the publisher. The CCC fee code is $0277-786 \mathrm{X} / 07 / \$ 18.00$.

Printed in the United States of America.

Publication of record for individual papers is online in the SPIE Digital Library.

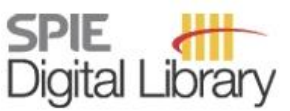

SPIEDigitalLibrary.org

Paper Numbering: Proceedings of SPIE follow an e-First publication model, with papers published first online and then in print and on CD-ROM. Papers are published as they are submitted and meet publication criteria. A unique, consistent, permanent citation identifier (CID) number is assigned to each article at the time of the first publication. Utilization of CIDs allows articles to be fully citable as soon they are published online, and connects the same identifier to all online, print, and electronic versions of the publication. SPIE uses a six-digit CID article numbering system in which:

- The first four digits correspond to the SPIE volume number.

- The last two digits indicate publication order within the volume using a Base 36 numbering system employing both numerals and letters. These two-number sets start with $00,01,02,03,04,05$, 06, 07, 08, 09, OA, OB ... 0Z, followed by 10-1Z, 20-2Z, etc.

The CID number appears on each page of the manuscript. The complete citation is used on the first page, and an abbreviated version on subsequent pages. Numbers in the index correspond to the last two digits of the six-digit CID number. 


\section{Contents}

ix Conference Committee

\section{SESSION 1 MIRRORS}

667102 JWST mirror technology development results [6671-01]

H. P. Stahl, NASA Marshall Space Flight Ctr. (USA)

667105 Kepler primary mirror assembly: FEA surface figure analyses and comparison to metrology [6671-04]

J. W. Zinn, G. W. Jones, L-3 Communications Brashear (USA)

667106 Manufacturing meter-scale aspheric optics [6671-05]

W. Messner, C. Hall, P. Dumas, B. Hallock, M. Tricard, S. O'Donohue, QED Technologies Inc. (USA); S. Miller, The Univ. of Arizona (USA)

667107 Fabrication and testing of large flats [6671-06]

J. Yellowhair, Sandia National Labs. (USA); P. Su, M. Novak, J. Burge, College of Optical

Sciences, The Univ. of Arizona (USA)

\section{SESSION 2 SYSTEMS}

667108 Vertically configured collimator for cryogenic vacuum testing of meter scale optical systems [6671-07]

D. Sabatke, S. Meyer, N. Siegel, D. Byrd, P. Spuhler, P. Atcheson, M. Martella, E. Penniman, Ball Aerospace \& Technologies Corp. (USA)

667109 Manufacturing development of visor for binocular helmet mounted display [6671-08] D. Krevor, T. Edwards, E. Larkin, Rockwell Collins Display Systems (USA); J. Skubon, MXL Industries (USA); R. Speirs, Ferris State Univ. (USA); T. Sowden, Contour Metrological and Manufacturing (USA)

$6671 \mathrm{OA}$ Structure function analysis of mirror fabrication and support errors [6671-09]

A. M. Hvisc, J. H. Burge, College of Optical Sciences, The Univ. of Arizona (USA)

\section{SESSION 3 NEW MEASUREMENT METHODS}

6671 OE Frequency response of the three Gaussian beam interferometric profilometer [6671-13] L. Juárez P., J. M. Flores, M. Cywiak, M. Servín, Ctr. de Investigaciones en Óptica, A.C. (Mexico) 
$6671 \mathrm{OH}$ Thermal shock testing of lapped optical glass [6671-17]

Y. Zhang, Y. WU, H. Liu, Univ. of Rochester (USA); J. C. Lambropoulos, Univ. of Rochester (USA) and Lab. for Laser Energetics (USA)

6671 ol In-process non-destructive subsurface damage measurements and correlations to both laser damage and surface roughness [6671-18]

K. C. Robinson, A. Ghanbhari, T. Kamprath, J. Nelson, VLOC (USA)

6671 0J MRF spotting technique for studying subsurface damage in deterministic microground polycrystalline alumina [6671-19]

S. N. Shafrir, J. C. Lambropoulos, S. D. Jacobs, Univ. of Rochester (USA)

6671 OK Moore's law and mold making: staying in the megapixel race [6671-20]

K. Renkema, Philips High Tech Plastics (Netherlands)

$6671 \mathrm{OL}$ High-precision aspheres for professional cine lenses: design and manufacturing [6671-21]

T. Köhler, Carl Zeiss Jena GmbH (Germany); C. Beder, Carl Zeiss AG (Germany)

\section{SESSION 5 INTERFEROMETRY I}

$6671 \mathrm{OM}$ Surface reconstruction based on transmission interferometric testing [6671-22]

K. Seong, J. E. Greivenkamp, College of Optical Sciences, The Univ. of Arizona (USA)

$6671 \mathrm{ON}$ New interferometric technique to measure the length (thickness) of opaque objects using a commercial interferometer [6671-23]

A. R. Suratkar, A. D. Davies, F. Farahi, Univ. of North Carolina at Charlotte (USA)

6671 OP Segmented wave-front measurements by lateral shearing interferometry [6671-25]

B. Toulon, J. Primot, N. Guérineau, Office National d'Études et de Recherches Aérospatiales (France); S. Velghe, Phasics SA, XTEC (France); R. Haïdar, Office National d'Études et de Recherches Aérospatiales (France)

6671 OR Shear test of the off-axis surface with an axis-symmetric parent [6671-27]

P. Su, J. H. Burge, J. Sasian, College of Optical Sciences, The Univ. of Arizona (USA)

\section{SESSION 6 INTERFEROMETRY II}

6671 OT Weighted least-square approach for simultaneous measurement of multiple reflective surfaces [6671-29]

S. Tang, R. E. Bills, K. Freischlad, KLA-Tencor (USA)

6671 OU Measuring surface slope error on precision aspheres [6671-59]

J. J. Kumler, Coastal Optical Systems (USA); J. B. Caldwell, Caldwell Photographic (USA)

$6671 \mathrm{OV}$ Speckle metrology based study on the effect of chattering on machined surfaces [6671-31] P. C. Ashok, U. Nair, V. Kas, V. N. N. Namboothiri, V. P. N. Nampoori, Cochin Univ. of Science and Technology (India) 
6671 OW Design of partial nulls for testing of fast aspheric surfaces [6671-32]

J. J. Sullivan, J. E. Greivenkamp, College of Optical Sciences, Univ. of Arizona (USA)

6671 OX 3-dimensional scanning of grinded optical surfaces based on optical coherence tomography [6671-33]

T. Hellmuth, R. Börret, K. Khrennikov, Aalen Univ. of Applied Sciences (Germany)

\section{SESSION 7 NOVEL FINISHING}

6671 OY Calculation of MRF influence functions [6671-34]

M. Schinhaerl, Univ. of Applied Sciences Deggendorf (Germany) and Univ. of the West of England (United Kingdom); G. Smith, Univ. of the West of England (United Kingdom); A. Geiss, Univ. of Applied Sciences Deggendorf (Germany); L. Smith, Univ. of the West of England (United Kingdom); R. Rascher, P. Sperber, Univ. of Applied Sciences Deggendorf (Germany); E. Pitschke, Univ. of Applied Sciences Deggendorf (Germany) and Univ. of the West of England (United Kingdom); R. Stamp, Univ. of the West of England (United Kingdom)

$6671 \mathrm{OZ}$ The role of nanodiamonds in the polishing zone during magnetorheological finishing (MRF) [6671-35]

J. E. DeGroote, Univ. of Rochester (USA) and The Institute of Optics, Univ. of Rochester (USA); A. E. Marino, Univ. of Rochester (USA); J. P. Wilson, A. L. Bishop, S. D. Jacobs, Univ. of Rochester (USA) and The Institute of Optics, Univ. of Rochester (USA)

667110 Magnetorheological fluid template for basic studies of mechanical-chemical effects during polishing [6671-36]

C. Miao, Univ. of Rochester (USA); K. M. Bristol, U.S. Army ARDEC (USA); A. E. Marino, S. N. Shafrir, Univ. of Rochester (USA); J. E. DeGroote, Optimax Systems, Inc. (USA);

S. D. Jacobs, Univ. of Rochester (USA)

667111 Complete sub-aperture pre-polishing and finishing solution to improve speed and determinism in asphere manufacture [6671-37]

P. Dumas, C. Hall, B. Hallock, M. Tricard, QED Technologies International (USA)

667113 High-speed form preserving polishing of precision aspheres [6671-39]

R. Boerret, A. Kelm, Univ. of Applied Science Aalen (Germany); H. Thiess, Carl Zeiss AG (Germany)

667114 Correction of high spatial frequency errors on optical surfaces by means of ion beam figuring [6671-40]

M. Ghigo, INAF-Osservatorio Astronomico di Brera (Italy); R. Canestrari, INAF-Osservatorio Astronomico di Brera (Italy) and Univ. degli Studi dell'Insubria (Italy); D. Spiga, INAFOsservatorio Astronomico di Brera (Italy); A. Novi, Galileo Avionica (Italy)

\section{POSTER SESSION}

667115 Non-destructive evaluation (NDE) using multi-aperture DSPI system and fast Fourier transform method [6671-30]

B. Bhaduri, N. Krishna Mohan, M. P. Kothiyal, Indian Institute of Technology Madras (India) 
667116 An analytical method for measuring the decentration of lens module [6671-41] C.-W. Chang, Industrial Technology Research Institute (Taiwan)

667117 Optical tests of a space mechanism under an adverse environment: GAIA secondary mirror mechanism under vaccum and thermal controlled conditions [6671-42] G. Ramos Zapata, A. Sánchez Rodríguez, T. Belenguer Dávila, Instituto Nacional de Técnica Aeroespacial (Spain); E. Urgoiti, A. Ramírez Quintana, SENER (Spain)

667119 Aspheric measurement based on the curvature sensing method [6671-44] Y. Kwon, B. Kim, D. H. Wang, Kyungnam Univ. (South Korea); Y. Lee, H. Yang, H. Rhee, Korea Research Institute of Standards and Science (South Korea)

6671 1A Simulation and uncertainty analysis for Hartmann-Shack wavefront sensor [6671-45] C. C. Chang, Industrial Technology Research Institute (Taiwan) and National Central Univ. (Taiwan); C. C. Lee, National Central Univ. (Taiwan)

6671 1B Three-dimensional imaging with acousto-optic fringe projector and piecewise temporal phase unwrapping [6671-46] J. Tian, X. Zhao, Shenzhen Univ. (China); X. Liu, Shenzhen Univ. (China) and Tianjin Univ. (China); X. Peng, Shenzhen Univ. (China)

6671 1C Tellurite glass fiber fabrication and drawing furnace analysis [6671-47] X. Wang, Q. Nie, T. XU, S. Dai, C. Xu, J. Huang, Ningbo Univ. (China); L. Liu, Shanghai Institute of Optics and Fine Mechanics (China)

6671 1D Phase detection from two phase-shifting interferograms [6671-49]

Y. Zhu, L. Liu, Y. Zhi, Z. Luan, D. Liu, Shanghai Institute of Optics and Fine Mechanics (China)

6671 1E Fourier analysis of two-run-times-two-frame phase shift algorithm [6671-50]

X. Zhong, Shanghai Institute of Optics and Fine Mechanics (China)

$6671 \mathrm{lF}$ Fiber Bragg gratings for laser interferometry with VCSEL diode at $760 \mathrm{~nm}$ wavelength [6671-51]

B. Mikel, Institute of Scientific Instruments (Czech Republic); R. Helán, Institute of Scientific Instruments (Czech Republic) and Univ. of Technology Brno (Czech Republic); O. Číp, Institute of Scientific Instruments (Czech Republic)

$66711 G$ Extended range interferometry based on wavefront shaping [6671-53] M. L. Szczupak, L. Salbut, Warsaw Univ. of Technology (Poland)

$6671 \mathrm{HH}$ A quantitative comparison of three grolishing techniques for the Precessions process [6671-56]

D. D. Walker, Univ. College London (United Kingdom) and Zeeko Ltd. (United Kingdom); A. Baldwin, Cranfield Univ. (United Kingdom); R. Evans, Univ. College London (United Kingdom); R. Freeman, Zeeko Ltd. (United Kingdom); S. Hamidi, OpTIC Technium (United Kingdom); P. Shore, X. Tonnellier, Cranfield Univ. (United Kingdom); S. Wei, Zeeko Ltd. (United Kingdom); C. Williams, QioptiQ (United Kingdom); G. Yu, Univ. College London (United Kingdom)

667111 High performance optical materials cyclo olefin polymer ZEONEX [6671-58]

K. Obuchi, M. Komatsu, K. Minami, Zeon Corp. (Japan) 
$66711 \mathrm{~J}$ Lens production enhancement by adoption of artificial influence functions and a knowledge-based system in a magnetorheological finishing process [6671-60]

E. Pitschke, Univ. of Applied Sciences Deggendorf (Germany) and Univ. of the West of England (United Kingdom); P. Sperber, R. Rascher, Univ. of Applied Sciences Deggendorf (Germany); R. Stamp, M. Smith, L. Smith, Univ. of the West of England (United Kingdom); M. Schinhaerl, Univ. of Applied Sciences Deggendorf (Germany)

Author Index 
Downloaded From: https://www.spiedigitallibrary.org/conference-proceedings-of-spie on 26 Apr 2023

Terms of Use: https://www.spiedigitallibrary.org/terms-of-use 


\title{
Conference Committee
}

\author{
Conference Chairs
}

James H. Burge, College of Optical Sciences, The University of Arizona (USA)

Oliver W. Faehnle, FISBA OPTIK AG (Switzerland)

Ray Williamson, Ray Williamson Consulting (USA)

Program Committee

Dave Baiocchi, Sandia National Laboratories (USA)

Michael Bray, MB Optique SARL (France)

Andrew R. Clarkson, L-3 Brashear (USA)

Glen C. Cole, L3 Communications Tinsley (USA)

David A. Content, NASA Goddard Space Flight Center (USA)

Peter J. de Groot, Zygo Corporation (USA)

Roland Geyl, SAGEM SA (France)

John E. Greivenkamp, College of Optical Sciences, The University of Arizona (USA)

Stephen D. Jacobs, University of Rochester (USA) and The Institute of Optics, University of Rochester (USA)

Stephen E. Kendrick, Ball Aerospace \& Technologies Corporation (USA)

Stephen J. Martinek, 4D Technology Corporation (USA)

Gary Matthews, ITT Industries, Inc. (USA)

Robert E. Parks, Optical Perspective Group, LLC (USA)

Joseph L. Robichaud, L-3 SSG-Tinsley (USA)

Joanna Schmit, Veeco Instruments Inc. (USA)

Peter Z. Takacs, Brookhaven National Laboratory (USA)

Martin J. Valente, College of Optical Sciences, The University of Arizona (USA)

David D. Walker, University College London (United Kingdom) and Zeeko Ltd. (United Kingdom)

Xuejun Zhang, Changchun Institute of Optics, Fine Mechanics and Physics (China)

Session Chairs

1 Mirrors

Dave Baiocchi, Sandia National Laboratories (USA) 
2 Systems

Stephen E. Kendrick, Ball Aerospace \& Technologies Corporation (USA)

3 New Measurement Methods

Andrew R. Clarkson, L-3 Brashear (USA)

$4 \quad$ Materials, Forming

David D. Walker, University College London (United Kingdom) and Zeeko Ltd. (United Kingdom)

5 Interferometry I

John E. Greivenkamp, College of Optical Sciences, The University of Arizona (USA)

6 Interferometry II

Ray Williamson, Ray Williamson Consulting (USA)

$7 \quad$ Novel Finishing

Oliver W. Faehnle, FISBA OPTIK AG (Switzerland) 